\title{
Sclerosing Mucoepidermoid Carcinoma in the Parotid Gland: Literature Review
}

\author{
Chang-Ki Woo, Bae-Hyun Kim, Byung-Joo Lee and Jin-Choon Lee \\ Department of Otorhinolaryngology-Head and Neck Surgery, Pusan National University School of Medicine, Busan, Korea
}

\section{이하선에 발생한 경화 점액표피양 암종 1예: 문헌고찰}

우창기 · 김배현 · 이병주 · 이진춘

부산대학교 의학전문대학원 이비인후과학교실

\author{
Received March 26, 2012 \\ Revised May 7, 2012 \\ Accepted May 14, 2012 \\ Address for correspondence \\ Jin-Choon Lee, MD \\ Department of Otorhinolaryngology- \\ Head and Neck Surgery, \\ Pusan National University School \\ of Medicine, 179 Gudeok-ro, Seo-gu, \\ Busan 602-739, Korea \\ Tel $+82-51-240-7335$ \\ Fax +82-51-246-8668 \\ E-mail1jc0209@hanmail.net
}

\begin{abstract}
Mucoepidermoid carcinoma is the most common malignant salivary gland neoplasm. Its sclerosing morphologic variant, however, is an extremely rare entity. Only 15 cases have been reported in the English literature. We report a case of a sclerosing mucoepidermoid carcinoma in the left parotid gland with a review of literature. A fifty seven-year-old female patient presented with left parotid mass. Fine needle aspiration biopsy reported a parotid gland tumor, predominantly benign cystic condition, and the differential diagnosis included benign lymphoepithelial cyst and Warthin' tumor. Left superficial parotidectomy was performed. Histologically, a well demarcated mass $(2.2 \times 1.5 \times 1.0 \mathrm{~cm})$ was composed of a central sclerosis with a few tumor nests and a peripheral lymphoid hyperplasia. The lumen of the tumor glands is filled with mucin stained with mucicarmine. Finally, it was diagnosed as sclerosing mucoepidermoid carcinoma. Korean J Otorhinolaryngol-Head Neck Surg 2012;55:508-12
\end{abstract}

Key Words Parotid gland · Sclerosing mucoepidermoid carcinoma.

\section{서 론}

점액표피양 암종(mucoepidermoid carcinoma)은 가장 흔 한 악성침샘종양으로 경화성(sclersing), 단방성(unicystic), 호산성 과립세포성(oncocytic), 피지성(sebaceous), 투명세포 (clear cell), 배상세포 침습성(goblet cell aggressive), 방추세 포(spindle cell), 사종성(psammomatous) 등의 여러 조직학적 변이가 있다. ${ }^{1)}$ 이 중 경화 점액표피양 암종(sclerosing mucoepidermoid carcinoma)은 점액표피양 암종의 매우 드문 아형 으로, 극심한 중심성 경화가 보이고 그 주변으로 염증성 형질 세포, 호산구, 림프구의 침윤이 종양의 대부분에서 관찰되기 때문에 염증 과정으로 혼동되어 종종 진단이 어렵기도 하다. ${ }^{2)}$ 전 세계적으로 15 여편 정도만 보고된 아주 드문 질환으로, 저 자들은 최근 임상적으로 양성 이하선 종양으로 의심되고 세 침흡인세포검사에서 와르틴 종양으로 오진되었으며 동결절
편검사에서도 양성으로 진단되었던 경화 점액표피양 암종 1 예를 경험하였기에 그 병리학적 소견을 보고하여 경험을 공 유하고 해외에 보고된 15예 및 국내에 보고된 2예의 문헌 고찰 을 통해 임상적 특성을 분석하고자 한다.

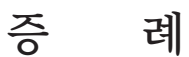

57세 여자가 좌측 이하선의 종괴를 주증상으로 내원하였다. 종괴는 약 4개월 전부터 인지되었으나 별다른 조치 없이 경과 관찰하며 지내던 중 통증이 생겨 2차 병원 방문하여 실시한 경부 초음파 결과 좌측 이하선 종물이 발견되었다. 외부병원 에서 실시한 자기공명영상 $\mathrm{T} 1$ 에서 저음영, $\mathrm{T} 2$ 에서 고음영을 보이는 $1.5 \times 1.0 \mathrm{~cm}$ 의 경계가 분명하지 않은 종괴로(Fig. 1), 본 원에서 실시한 세침흡인검사에서 양성 낭성 상태의 병변으로 와르틴 종양(Warthin's tumor) 또는 양성 림프표피 낭종이 추 

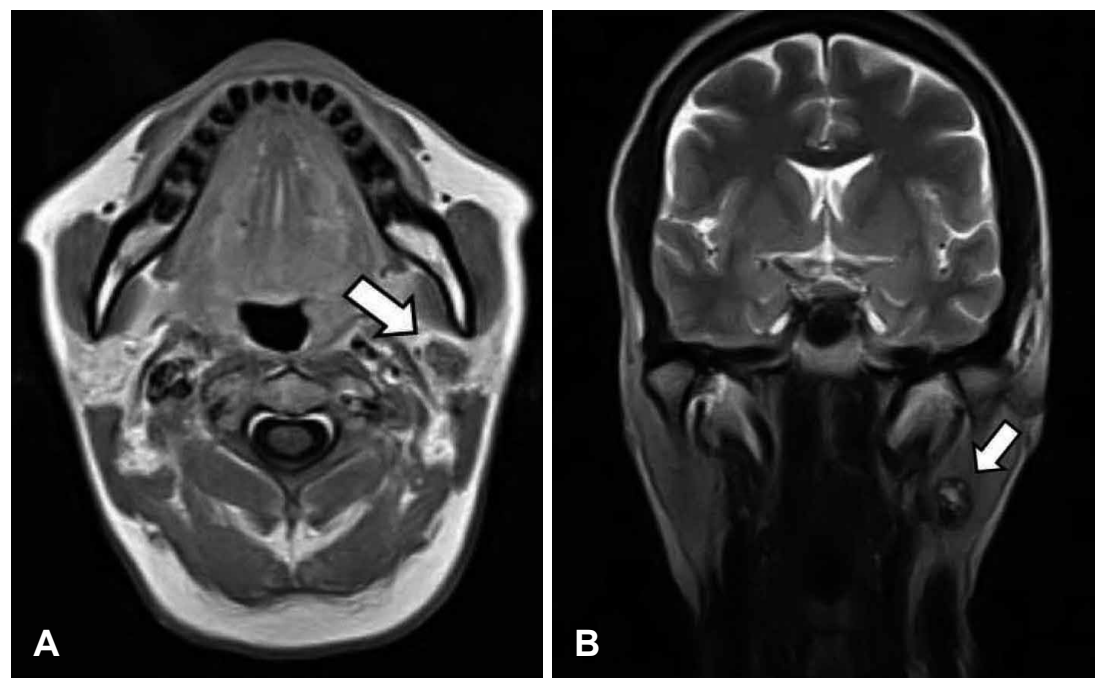

Fig. 1. Preoperative brain MRI findings. T1 weighted axial image shows irregular shaped mass $(12 \times 8 \mathrm{~mm})$ with low signal intensity in the left parotid gland (arrow)(A). T2 weighted coronal image shows oval shaped \& circumscribed mass $(19 \times 12 \mathrm{~mm})$ with central high signal intensity in the left parotid gland (arrow) (B)
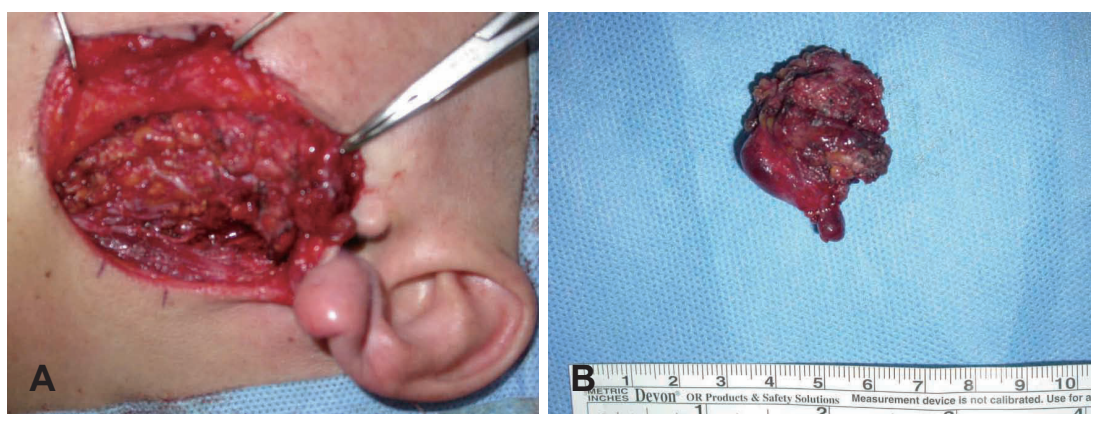

Fig. 2. Operative finding and the specimen. The intraoperative picture shows that left superficial parotidectomy had done with preserving a branch of facial nerve (A). The specimen shows an well-defined mass with parotid gland tissue $(33 \times 33 \mathrm{~mm})(B)$.

정되었다. 이상의 소견을 통해 종괴는 좌측 이하선 기원의 양 성 종양으로 판단되어, 이하선천엽절제술을 시행하였다.

수술실 소견으로 종괴는 이하선 미부의 실질에 위치하고 있 었으며, 안면신경의 하악분지와 경한 유착이 있었으나 비교적 수월하게 박리가 되었다. 수술 중 동결절편검사에서 양성 낭종 질환이라는 보고가 있어 천엽절제술을 통해 병변이 완전히 제 거된 것으로 판단하여 수술을 종료하였다(Fig. 2A).

종괴의 육안 검사상 크기가 약 $3 \mathrm{~cm}$ 였고 경계가 분명한 낭 성 종물이었다. 현미경검사 및 특수염색 결과 저등급 경화 점 액표피양 암종으로 최종 진단되었다.

육안적으로 절제된 이하선 조직의 크기는 $3.3 \times 3.3 \times 1.5 \mathrm{~cm}$ 였고, 단면상 $2.2 \times 1.5 \times 1.0 \mathrm{~cm}$ 의 비교적 경계가 좋은 백색의 낭성 종물이 관찰되었다(Fig. 2B). 현미경 소견으로 종괴는 저 배율에서 경계가 좋은 결절 모양이었고, 크게 중심부의 심한 섬유화를 보이는 부분과, 주변부의 풍부한 림프구 침윤을 보 이는 부분으로 구분되었다. 섬유화를 보이는 중심부에는 점액 양 물질을 함유한 확장된 관 또는 선 구조가 관찰되었다(Fig. 3). 선 내부의 물질은 특수 염색(PAS, D-PAS, mucicarmine)을 시행하여 점액임을 확인하였다. 고배율에서 관, 또는 선을 이 루는 상피 세포는 저등급의 점액을 함유한 세포와 편평 상피

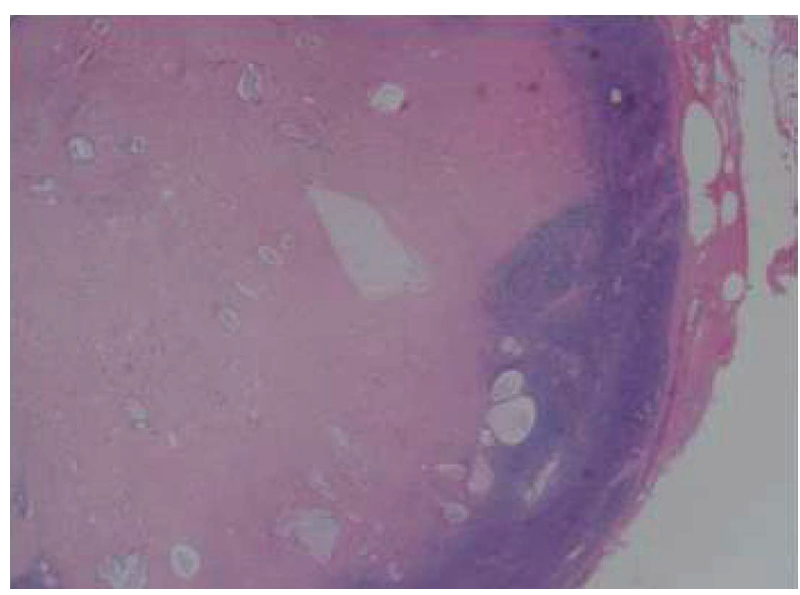

Fig. 3. A low power view $(H \& E$ stain, $\times 20)$ shows well demarcated mass, composed of a central sclerosis with a few tumor nests and a peripheral lymphoid hyperplasia.

를 닮은 중간형 세포였다(Fig. 4). 세포 밀도는 매우 낮았으며, 괴사나 감수분열은 관찰되지 않았다. 주변부의 림프구가 풍 부한 부분을 확대하였을 때 이를 구성하는 세포는 주로 림프 구, 형질세포였고 현저한 림프여포 형성이 관찰되었다(Fig. 5). 이상의 소견을 바탕으로 종괴는 저등급 경화성 점액표피양 암 종으로 진단되었고, 절제연에서 종양은 관찰되지 않았다. 
Fig. 4. The central area shows islands of tumor nests composed of flattened mucin-secreting cells and epidermoid cells, within keloid-like stroma (H\&E stain, $\times 40)(A)$. The lumen of the tumor glands is filled with mucin stained with mucicarmine $($ H\&E stain, $\times 400)(B)$.
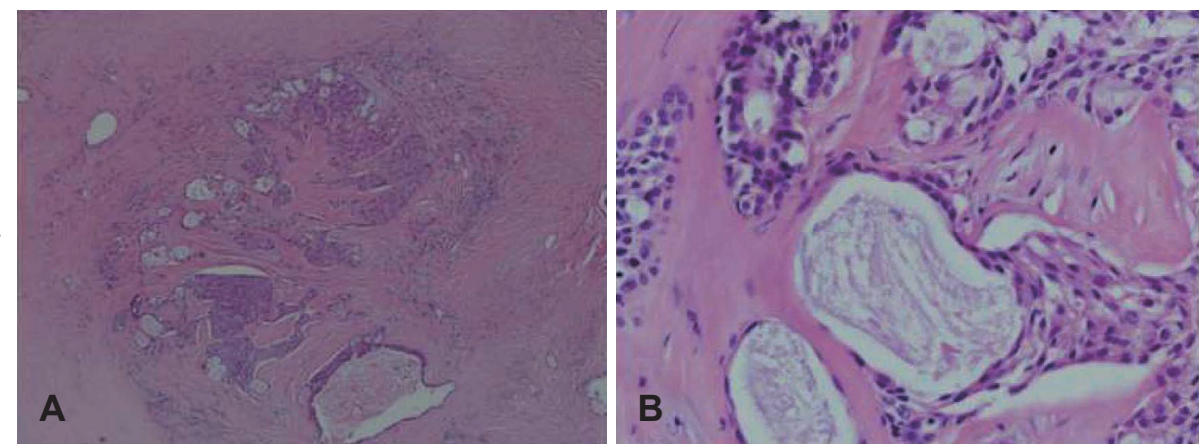

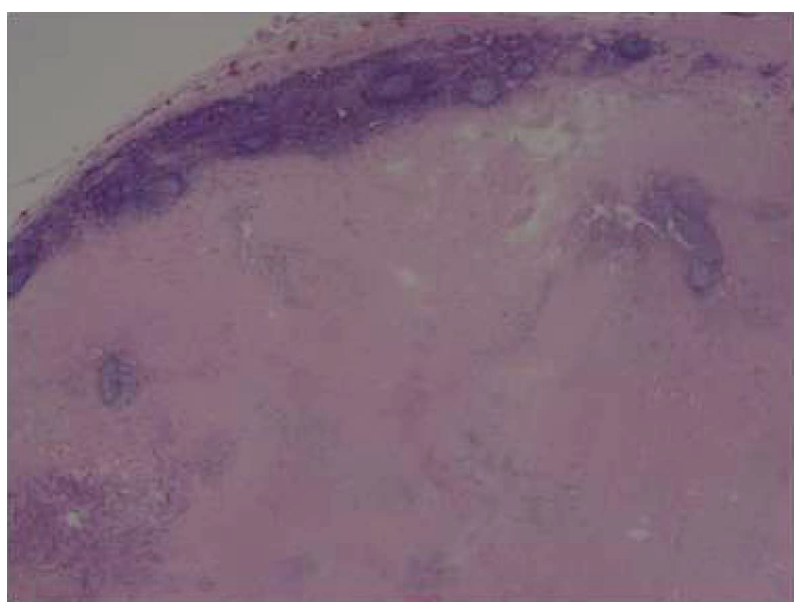

Fig. 5. Peripheral portion of the tumor, composed of dense lymphoplasmacytic infiltration with germinal center (H\&E stain, $\times 40$ ).

이후 특별한 부작용 없이 퇴원한 환자는 주기적으로 외래 경과 관찰을 시행하는 중이며, 술 후 6개월에 실시한 양전자 방출 단층촬영 및 술 후 1 년에 실시한 이하선 컴퓨터 단층촬 영 결과 재발 소견 보이지 않았다.

\section{고 찰}

점액표피양 암종은 전체 침샘종양의 $16 \%$, 침샘악성종양의 약 $30 \%$ 를 차지한다. ${ }^{3)}$ 점액성, 표피양성, 중간성, 투명세포성의 다양한 비율이 혼합되어 있고 때로 현저한 낭성 구조를 보인 다. 이런 병리 구조의 차이는 다양한 아형을 초래한다. 형태와 세포적인 모양에 기초해 저도, 중도, 고도의 등급이 정해진다.) 병리등급, 병기, 병리 아형, 특수 염색에 따라 예후가 달라진다. ${ }^{5)}$ 경화 점액표피양 암종은 유리질화, 섬유화, 낭성 표피를 둘 러싸고 있는 켈로이드 섬유를 특징으로 한다. 종양은 캡슐을 형성하지 않지만 경계가 좋은 편이다. 가끔 종양의 주변부에 배중심을 형성하는 림프 조직이 현저하며, 이는 이하선내 림프 절 전이로 오진될 수도 있다.)

이 암종은 경화 다낭선증, 만성 경화 침샘염, 저등급 낭선 암 종 등과 감별이 필요하다. 경화 다낭선증은 침샘에 드문 질환
으로 엽 구조 보존, 이중 상피층의 확장된 관 소견을 보여 경 화 점액표피양 암종과 감별된다.' Kuttner's tumor로 불리는 만성 경화 침샘염은 낭 성분이 부족하기 때문에 경화 점액표 피양 암종과 구별된다. 또한 악하선에 호발하며, 엽구조가 보 존되는 특징도 있다. 저등급 낭선 암종은 낭 성분이 현저한 유 사점이 있으나 표피양 특성이 드문 것이 경화 점액표피양 암종 과의 차이점이다. ${ }^{8)}$

갑상선 기원의 경화 점액표피양 암종은 1991 년에 Chan에 의 해 처음 보고되었으며 하시모토 갑상선염이 있는 60세 이상의 여성에서 발생하는 경향이 있다.' 조직학적으로 호산군 침윤 을 동반한 점액분비샘과 편평세포의 혼합물을 섬유조직형성 기질이 둘러싸 경화를 보이는 특징이 있으며, 상대적으로 느린 임상 경과를 보이나 일부에서는 공격적으로 림프절 전이를 보 이는 경우가 보고되고 있다. ${ }^{10)}$

침샘의 경화 점액표피양 암종은 $\mathrm{Chan}$ 과 $\mathrm{Saw}^{11)}$ 에 의해 1987 년 처음으로 기술되었다(Table 1). 흥미롭게도 그 보고의 환 자는 술 전 세침흡입검사에서 다형성 선종으로 진단되었다. 10 년 뒤 Muller 등ㅎㅇㅔ 의해 추가로 2예가 보고되었다. 1999년에 Sinha 등 ${ }^{12)}$ 이 65세 남자 환자를 보고했다. 날개근과 두개저 부에 침범을 보이는 고도 경화 점액표피양 암종으로 이는 소 침샘에서 기원한 첫 보고였다.

2002년에 Urano 등 ${ }^{13)}$ 은 중도 경화 점액표피양 암종 2예를 보고했다. 광범위 기질 호산구 침윤이 있었으며 이는 호산구증 경화 점액표피양 암종(sclerosing mucoepidermoid carcinoma with eosinophilia)으로 갑상선에서만 주로 보고되던 것이었 다. 또한 이들은 처음으로 특수염색에 대한 기술을 남겼으며, 2예 모두에서 EMA, Cytokeratin, CEA 양성, GFAP, S-100, smooth muscle actin, p53 음성이었고, 각각 MIB-1 labeling index가 $4.5 \%, 7.2 \%$ 였다.

Fadare 등 ${ }^{14)}$ 과 Heavner 등 ${ }^{15)}$ 도 각각 이하선 종물을 호소 하는 44세 여자와 23세 여자를 보고했으며 두 저자는 저도의 분화도를 보이는 경화 점액표피양 암종에 대한 치료로 이하선 전절제술과 술 후 방사선 치료를 선택하였다. 2007년에 Veras 등 $^{16)}$ 은 단일 보고로는 제일 많은 4예를 보고하였고, Mayer 
Sclerosing Mucoepidermoid Carcinoma in the Parotid Gland I Woo CK, et al.

Table 1. Reported cases in previous English literature regarding the sclerosing mucoepidermoid carcinoma of salivary glands

\begin{tabular}{|c|c|c|c|c|c|c|c|c|c|c|}
\hline Source & $\begin{array}{l}\text { Sex/Age } \\
\text { (years) }\end{array}$ & Symptom & $\begin{array}{l}\text { Period } \\
\text { (years) }\end{array}$ & FNAB & Site & Grade & $\mathrm{E} \varphi$ & Treatment & \multicolumn{2}{|c|}{$\begin{array}{c}\text { F/U } \\
\text { (months) }\end{array}$} \\
\hline Chan and Saw ${ }^{11)}$ & $M / 36$ & $\begin{array}{l}\text { Painless swelling \& mass over } \\
\text { the Lt. lower jaw }\end{array}$ & 1.5 & $\mathrm{PA}$ & $P$ & Low & $\mathrm{N} / \mathrm{A}$ & SP & \multicolumn{2}{|c|}{ N/A } \\
\hline Muller, et al. .6$)$ & $\mathrm{F} / 17$ & $\begin{array}{l}\text { Firm, tender palpable mass } \\
\text { of the Rt. parotid region }\end{array}$ & 0.5 & Unknown & $P$ & M & $N / A$ & $\mathrm{SP} \rightarrow \mathrm{TP}$ & \multicolumn{2}{|c|}{ N/A } \\
\hline Muller, et al. .6$)$ & $\mathrm{F} / 60$ & Mobile mass beneath Rt. ear & 1 month & Benign & $P$ & M & $N / A$ & $\mathrm{SP}+\mathrm{RTX}$ & \multicolumn{2}{|c|}{ N/A } \\
\hline Sinha, et al. ${ }^{12)}$ & $M / 65$ & $\begin{array}{l}\text { Pain \& stiffness in the Rt. } \\
\text { temperomandibular area }\end{array}$ & 0.5 & N-D & MSG* & High & N/A & $C R+R T x$ & \multicolumn{2}{|c|}{ N/A } \\
\hline Urano, et al. ${ }^{13)}$ & $\mathrm{F} / 57$ & $\begin{array}{l}\text { Gradually enlarged mass } \\
\text { in the Rt. parotid region }\end{array}$ & 1.5 & N/A & $P$ & Low & O & $\mathrm{SP} \rightarrow \mathrm{ND}$ & $R$ & 36 \\
\hline Urano, et al. ${ }^{13)}$ & $M / 43$ & $\begin{array}{l}\text { Gradually enlarged mass in } \\
\text { the Lt. submandibular region }\end{array}$ & 5.5 & N/A & $S M G$ & Low & O & $\mathrm{CR} \rightarrow \mathrm{ND}$ & $\begin{array}{l}\mathrm{R} \\
\mathrm{DOD}+\end{array}$ & $\begin{array}{l}16 \\
61\end{array}$ \\
\hline Fadare, et al. ${ }^{14)}$ & $\mathrm{F} / 44$ & Rt. facial mass & $\begin{array}{l}\text { Several } \\
\text { months }\end{array}$ & N/A & $P$ & Low & $\mathrm{N} / \mathrm{A}$ & $T P+R T x$ & NED & 84 \\
\hline Heavner, et al..$^{15)}$ & $\mathrm{F} / 23$ & Painful mass of the Lt. neck & $\begin{array}{c}2 \\
\text { months }\end{array}$ & $\begin{array}{l}\text { N-D/ } \\
\text { Benign }\end{array}$ & $\mathrm{P}$ & Low & O & $T P+R T x$ & NED & 12 \\
\hline Veras, et al. ${ }^{16)}$ & $\mathrm{F} / 70$ & Lt. parotid mass & 20 & N/A & $P$ & Low & O & $S P+N D$ & NED & 132 \\
\hline Veras, et al. ${ }^{16)}$ & $M / 37$ & Lt. parotid mass & Unknown & N/A & $P$ & Low & 0 & SP & NED & 204 \\
\hline Veras, et al. ${ }^{16)}$ & $F / 49$ & Rt. parotid mass & 3 & N/A & $P$ & Low & 0 & SP & NED & 4 \\
\hline Veras, et al. ${ }^{16)}$ & $F / 16$ & $\begin{array}{l}\text { Painless nodule in the Lt. } \\
\text { parotid region }\end{array}$ & 1 & N/A & $\mathrm{P}$ & M & O & SP & NED & 10 \\
\hline Aguiar, et al. ${ }^{17)}$ & $\mathrm{F} / 43$ & $\begin{array}{l}\text { Painful swelling over the Rt. } \\
\text { palatal area }\end{array}$ & 2 & N/A & MSG & Low & O & PM & NED & 19 \\
\hline Shinhar ${ }^{2)}$ & $\mathrm{F} / 57$ & $\begin{array}{l}\text { Painless, nontender mass in } \\
\text { the Lt. parotid gland }\end{array}$ & 6 & $N-D$ & $P$ & M & $N / A$ & $S P+R T x$ & NED & 36 \\
\hline $\begin{array}{l}\text { Mendelson, } \\
\text { et al. }{ }^{18)}\end{array}$ & $F / 21$ & Lt. neck mass, facial pain & 8 months & $\begin{array}{l}\mathrm{N}-\mathrm{D} \\
/ \mathrm{N}-\mathrm{D}\end{array}$ & $P$ & N/A & $\mathrm{N} / \mathrm{A}$ & $\begin{array}{l}\mathrm{SP} \rightarrow \\
\mathrm{TP}+\mathrm{ND}\end{array}$ & NED & 36 \\
\hline
\end{tabular}

*right parapharyngeal space, +lung metastasis. Rt.: right, Lt.: left, FNAB: fine needle aspiration biopsy, PA: pleomorphic adenoma, N-D: non-diagostic, N/A: not available, P: parotid, MSG: minor salivary gland, SMG: submandibular gland, M: intermediate, $\mathrm{E} \varphi$ : eosinophilia, SP: superficial parotidectomy, TP: total parotidectomy, RTX: radiotherapy, ND: neck dissection, CR: complete resection, PM: partial maxillectomy, F/U: follow up, R: recur, DOD: died of disease, NED: no evidence of disease

mucicarmine, MIB-1, HER-2/neu 등의 특수 염색을 실시하 였다. 2008년 Aguiar 등 ${ }^{17)}$ 은 palate의 minor salivary gland 에서 발생한 경화 점액표피양 암종을 보고하였고, $\mathrm{Ki}-67, \mathrm{c}^{-}$ erbB-2 특수염색을 실시하였다. 2009년 Shinhar, 2010년 Mendelson 등 ${ }^{18}$ 도 이하선에서 발생한 경화 점액표피양 암종 을 각각 1예 보고하였다.

이하선 기원의 경화 점액표피양 암종의 국내 보고는 $\mathrm{Kim}$ 등 ${ }^{19)}$ 이 2007년 병리학회지에 보고한 것이 첫 사례이며, 2008 년에 Lee 등이 이 한이인지에 보고한 것이 두 번째이다.

영어권에 보고된 15예에서 환자의 평균 발병 나이는 42세 (16 70세)였고, 남성은 4명, 여성은 11명으로 여성에서 우세하 게 나타났다. 환자가 호소하는 주증상은 종물이었으며 이 중 4 예에서 통증이 동반되었고, 의료기관을 방문하기까지 1 개월 에서 길게는 20년까지 다양한 임상 양상을 보였다. 수술 전 세 침흡입검사를 시행한 7예 중 양성으로 진단된 경우가 2예, 비 진단적으로 나온 경우가 5예 있었고, 8예에서 혈중 호산구증 가증을 보였다. 대부분인 13 예에서 이하선 기원을 보였으며, 2 예에서 소침샘, 1 예에서 악하선 기원을 보였다. 소침샘에서 발 생한 1예에서 날개근과 두개저부에 침윤을 보인 것을 제외하
면 대부분의 경우에서 주변 조직으로 침윤을 보이지 않았다. 이하선의 경화 점액표피양 암종 12 예 중 안면신경마비를 보 이는 경우는 없었다. 기록이 명시되어 있는 13예 중 2예만이 경 부림프절 전이가 있었고, 나머지 11 예에서는 경부림프절전이 가 없었다. 조직의 분화도가 명기된 14예 중 9예는 저도, 4 예는 중도, 1 예는 고도 분화를 보였다.

이하선 종양에 대해서는 안면신경을 보존하는 이하선천엽 절제술 또는 전절제술과 같은 수술이 최상의 치료법이다. 경부 림프절 전이가 있으면 경부림프절청소술의 적응이 되며, 고도 경화 점액표피양 암종, 3,4 기, 광범위 신경, 혈관 침범, 절제연 침범, 이하선 심엽 침범이 있을 때 방사선 치료의 적응이 된다.3)

본 증례에서는 좌측이하선천엽절제술을 시행하였고, 수술 전 시행한 영상의학적 검사에서 경부림프절 전이를 의심할 만 한 소견이 없어 경부림프절청소술은 시행하지 않았다.

기존에 시행된 치료들을 살펴보면, 술 전 영상 평가에서 심엽 침범을 보이는 2예에서는 이하선전절제술을, 그 외 모든 경우 에서는 이하선천엽절제술을 초치료로 시행하였으며, 수술 후 병리결과에서 절제연 종양 침범을 보이는 4예 중 3 예에서는 방 사선 치료를 추가로 시행하였고, 1 예는 이하선전절제술과 경부 
림프절청소술을 추가로 시행하였다. 조직 분화도가 중등도 로 나온 4예 중 2 예는 방사선 치료를, 1 예는 추가적인 이하선 전절제술을 시행받았다. 경계가 좋고 저등급 종양에서는 대 부분 추가치료 없이 경과 관찰을 하였으며, 1 예에서만 동측 경부림프절에 재발을 보였고 추가 치료로는 경부림프절청소 술이 시행되었다.

경과 관찰이 기록된 11 예 중 9예는 수술 후 4개월에서 17년 동안 재발이 없었고, 이하선 기원의 1 예는 수술 후 36 개월에 재 발하여 경부림프절청소술을 시행받았으며, 악하선 기원의 1 예는 수술 후 16 개월에 재발하여 경부림프절청소술을 시행받 았으나 5년 후 폐전이로 사망하였다.

본 증례에서처럼 비록 수술 중 동결절편 검사 결과가 양성 으로 나오더라도 최종결과가 악성으로 바뀌는 경우가 발생할 수 있으므로 충분한 안정역을 두고 절제하는 것이 좋을 것으 로 사료된다. 또한 수술 후 최종 조직결과가 경화 점액표피양 암종으로 확진되면 종양의 분화도, 절제연 종양 침범 여부 등 을 확인해 적응증이 된다면 방사선 치료를 적극적으로 시행해 야 한다. 이후 경부림프절 재발을 유심히 관찰해야 하며, 재발 시 경부림프절청소술을 시행해야 한다.

\section{REFERENCES}

1) Brandwein MS, Ivanov K, Wallace DI, Hille JJ, Wang B, Fahmy A, et al. Mucoepidermoid carcinoma: a clinicopathologic study of 80 patients with special reference to histological grading. Am J Surg Pathol 2001;25 (7):835-45.

2) Shinhar SY. Sclerosing mucoepidermoid carcinoma of the parotid gland: case report. Ear Nose Throat J 2009;88(11):E29-31.

3) Ellis GL, Auclair PL. Atlas of tumor pathology-tumors of the salivary glands Third series, Fascicle 17. Washington DC, USA: Armed Forces Institute of Pathology;1996. p.155-71.

4) Batsakis JG, Luna MA. Histopathologic grading of salivary gland neoplasms: I. Mucoepidermoid carcinomas. Ann Otol Rhinol Laryngol 1990;99(10 Pt 1):835-8.

5) Luna MA. Salivary mucoepidermoid carcinoma: revisited. Adv Anat Pathol 2006;13(6):293-307.
6) Muller S, Barnes L, Goodurn WJ Jr. Sclerosing mucoepidermoid carcinoma of the parotid. Oral Surg Oral Med Oral Pathol Oral Radiol Endod 1997;83(6):685-90.

7) Gnepp DR, Wang LJ, Brandwein-Gensler M, Slootweg P, Gill M, Hille J. Sclerosing polycystic adenosis of the salivary gland: a report of 16 cases. Am J Surg Pathol 2006;30(2):154-64.

8) Huang C, Damrose E, Bhuta S, Abemayor E. Kuttner tumor (chronic sclerosing sialadenitis). Am J Otolaryngol 2002;23(6):394-7.

9) Chan JK, Albores-Saavedra J, Battifora H, Carcangiu ML, Rosai J. Sclerosing mucoepidermoid thyroid carcinoma with eosinophilia. A distinctive low-grade malignancy arising from the metaplastic follicles of Hashimoto's thyroiditis. Am J Surg Pathol 1991;15(5):438-48.

10) Shehadeh NJ, Vernick J, Lonardo F, Madan SK, Jacobs JR, Yoo $\mathrm{GH}$, et al. Sclerosing mucoepidermoid carcinoma with eosinophilia of the thyroid: a case report and review of the literature. Am J Otolaryngol 2004; 25(1):48-53.

11) Chan JK, Saw D. Sclerosing mucoepidermoid tumour of the parotid gland: report of a case. Histopathology 1987;11(2):203-7.

12) Sinha SK, Keogh IJ, Russell JD, O’Keane JC. Sclerosing mucoepidermoid carcinoma of minor salivary glands: a case report. Histopathology 1999; 35(3):283-4.

13) Urano M, Abe M, Horibe Y, Kuroda M, Mizoguchi Y, Sakurai K, et al. Sclerosing mucoepidermoid carcinoma with eosinophilia of the salivary glands. Pathol Res Pract 2002;198(4):305-10.

14) Fadare O, Hileeto D, Gruddin YL, Mariappan MR. Sclerosing mucoepidermoid carcinoma of the parotid gland. Arch Pathol Lab Med 2004;128(9):1046-9.

15) Heavner SB, Shah RB, Moyer JS. Sclerosing mucoepidermoid carcinoma of the parotid gland. Eur Arch Otorhinolaryngol 2006;263(10): 955-9.

16) Veras EF, Sturgis E, Luna MA. Sclerosing mucoepidermoid carcinoma of the salivary glands. Ann Diagn Pathol 2007;11(6):407-12.

17) Aguiar MC, Bernardes VF, Cardoso SV, Barbosa AA, Mesquita RA, Carmo MA. A rare case of sclerosing mucoepidermoid carcinoma arising in minor salivary glands with immunohistochemical evaluation. Minerva Stomatol 2008;57(9):453-7.

18) Mendelson AA, al-Macki K, Chauvin P, Kost KM. Sclerosing mucoepidermoid carcinoma of the salivary gland: case report and literature review. Ear Nose Throat J 2010;89(12):600-3.

19) Kim H, Lee JH, Lee ES, Kwon SY, Kim TK, Kim YS. Sclerosing mucoepidermoid carcinoma of the parotid gland: a case report. Korean J Pathol 2007;41(3):193-7.

20) Lee BC, Hong SW, Lee JS, Koh JS. Sclerosing mucoepidermoid carcinoma of the parotid gland. Korean J Otorhinolaryngol-Head Neck Surg 2008;51(12):1170-3. 